\title{
Evaluation of Railway Level Crossing Attributes on Accident Causation in Lagos, Nigeria.
}

\author{
Adeolu, O.Dina., Cornelius, O. Akanni., and Bamidele, A. Badejo. \\ Received: 0503 2016 / Accepted: 1307 2016 / Published online: 30122016 \\ C 2016 Faculty of Geography UGM and The Indonesian Geographers Association
}

\begin{abstract}
The study examines the contribution of Railway Level Crossing (RLC)physical attributes to accident occurrence using the12 major level crossings within the Lagos metropolis. The $48 \mathrm{~km}$ single track mainline section under consideration which barely make up $1.1 \%$ of the entire narrow gauge track network of the country within a 5 year period contributed about $45 \%$ of the total National crossing accidents recorded in Nigeria. The method of investigation involved recording the individual attributes of each RLC such asgates, pedestrian traffic, car traffic light, proximity of signage to crossing, vehicular traffic as dummy variables. The regression analysis was used to measure their effect on accidents. The result indicates gates, pedestrians and the location of signage had significant impact on accidents occurrence at level crossings within Lagos metropolis. Based on the findings, enhancement of active warning systems among other recommendations was suggested as potent counter measures for RLC accident reduction.
\end{abstract}

Keywords: Level, Crossing, Attributes, Accidents, Lagos Nigeria.

\begin{abstract}
Abstrak Penelitian menguji tingkat kontribusi atribut fisik dari perlintasan jalan kereta api terhadap kejadian kecelakaan menggunakan 12 perlintasan utama dalam kota metropolis Lagos. $48 \mathrm{~km}$ jalan utama tunggal menjadi pertimbangan yang hampir meningkat $1.1 \%$ dari seluruh trek sempit jaringan negara dalam jangka waktu 5 tahun menyumbang sekitar 45\% dari total kecelakaan perlintasan secara Nasional di Nigeria. Metode penelitian melibatkan catatan dari masing-masing atribut RLC seperti pintu gerbang, pejalan kaki, lampu lalu lintas mobil, kedekatan tanda penyebarangan, lalu lintas kendaraan sebagai variabel dumi. Analisis regresi digunakan untuk mengukur pengaruh dari atribut terhadap kecelakaan. Hasilnya menunjukkan pintu gerbang, pejalan kaki, dan lokasi tanda perlintasan mempunyai dampak signifikan pada kecelakaan dalam kota metropolis Lagos.Berdasarkan penemuan tersebut, perbaikan dari sistem peringatan aktif disarankan sebagai upaya mengurangi kecelakaan RLC.
\end{abstract}

Kata kunci : Tingkat, Perlintasan, Atribut, Kecelakaan, Lagos Nigeria.

\section{Introduction}

Intersections remain some of the most eventfullocations within any transportation traffic system as they are commonly associated with commotion, tension, delays and accidents [Asenime, and Mobereola, 2015; Kiunsi, 2013; Atomode, 2013]. While they commonly occur within modes, intersections between different modes of transportare rare except in the case of level crossing. This unique crossings occur at locations where railway tracks intersect with the road network on the same grade level. The attention on them across the globe have been on

Adeolu, O.Dina; Cornelius,O. Akanni; and Bamidele, A. Badejo Faculty of Social and Management Science, Olabisi Onabanjo University, Ago-Iwoye, Ogun State, Nigeria Email:dinaolu@gmail.com the increase due to the infrastructure expansion associated with road and rail due to increasing level of Urbanization. The most important concern associated with level crossing occurrence has however beenthat of accidents. When compared to the number of road accident victims, Railway Level Crossing (RLC) belong to one of the critical places within the road transport mode. Although collisions between vehicles and trains at level crossings account for only a small proportion of all road accidents and casualty figure, these accidents are however three times more likely to involve fatalities when compared to all other types of road crashes [Afxentis, 1994]. From the railway view point, they remain places with the highest accident rate. Level crossing accidents not only dominate in terms of frequency but also in the severity of their 
consequences when compared to every other type of railway accidents [Kumarand and Panday, 2013]. According to the Federal Railroad Administration of United States of America, motorist are 20 times more likely to die from collision with a train than with another road vehicle.

As a way to manage safe crossings at these crossings,priority or right of wayis normally awarded to railway vehicles over road vehicles. The reason for this is that railway vehicles normally require longer braking distance (depending on their weight and speed), several hundred times longer than that of road vehicles thereby putting them at higher risk. Another being their inability to engage in evasive actions like road vehicles [Edquist, et al. 2009]. Based on the fore going, there is no other area where the risk associated of RLC accidents becomes more obvious other than in urban areas. Level crossings located within metropolitan areas generally have sufficient numbers of trains and crossing users to such extent that hazard reduction guidelines require them to be equipped with active warnings, fences and pedestrian gates and other array of specialized signage to warn all users of their presence [Enokela and Ibanga, 2005].

Despite these measures however, RLC accidents remain common and an increasing source of concernfor safe railway operation globally. The European Transport Safety Council noted that the 114,000 level crossings existing within the European Union (EU) member states recorded about 573 significant accidents at level crossings resulting in 369 fatalities and 339 serious injury in year 2012. The UIC Global Safety Index (GSI) for EU member states in 2014 also indicates $82 \%$ of all accidents in that year were from external causes,from trespassers and level crossing users. In United States of America, the Federal Railroad Administration indicated there was a total of 1898 RLC accidents in 2015 alone 50\% occurring less than 5 miles from the motorist home FRA (2015) while India in the Asia continentrecorded 51 of such accidents in 2014 [Dubbudu, 2015].

In Nigeria the number of level crossing accidents recorded in recent years have equally been on the increase. This is as a result of the rehabilitation of the national narrow gauge track network and resumption of train services in the country [Odeleye, 2015]. Urban areas of Nigeria with more level crossings and vehicular activity have so far recorded more than a fair share of these accidents. Available data from Nigeria Railway Corporation the state owned corporation and the sole operator of train services indicates annual national record of RLC accidents increased from 6 in year 2010 to 36 in 2014 (figure 1). Lagos state, the chief commercial city of the country and the most densely populated area of Nigeriain year 2010 recorded only 1 out of the 6 RLC accidents recorded in the country. However in year 2011, a total of 6 accidents was recorded in the state, in subsequent years record soared to 14,11 and 20 level crossing accidents respectively. Between 2010 and 2014 the state had recorded a total of 50 accidents within its 12 level crossings with an average of 4.2 accidents per level crossing within the set period. When compared to the national statistics, the total accidents within the Lagos metropolitan area together make up about $45 \%$ of the total accidents that occurred across the country in the five year window under review.

The $40 \mathrm{~km}$ track stretch between Iddo in mainland Lagos and Ijoko the city suburb areaof the city make up the Lagos administrative district of NRC is about $1.1 \%$ of total track of the country. Incidentally tracks and level crossings within this section are the busiest consequently bearing the largest share of the total national accident record within the country. What ishowever unclear is if the RLC physical attributes and other environmental factorscould becontributing factor to the observed pattern of accidents along these intersections.

Studies suggest RLC accidents occur as a result of road users not detecting crossings or approaching trains, ignoring or misjudging the risk posed byan approaching train [Abraham, et al., 1998; Caird et al., 2002; Cairney, 2003; Edquist et al., 2009; Leibowitz, 1985; Wallace, et al., 2008; Wigglesworth, 2001; Yeh and Multer, 2008]. Other studies further hinged these accidents onlimited crossing, train visibility, inattention, distraction and lack of knowledge regarding level crossings [Caird et al., 2002; Edquist et al., 2009; Wallace, McCusker and Hirsch, 2008; Wigglesworth, 2001]. The work of Stephens and Ukpere [2011] also attributed unsafe behaviour of motor drivers generally to their lack of ability to imbibe emotional intelligence while on the road. 
Otherscholarly works have also focused their attention on the attributes of the RLC environment as a way to improving safety. The work of Borowsky et al. [2008] had observed that the drivers are less likely to identify the traffic signs when these signs are located at unexpected locations. The work of Crundall and Underwood (2011) also concluded that traffic information should be simplified for drivers particularly the inexperienced. Chen et al. [2008] determined that the lesser number of information signs, signals and pedestrians results in a higher accuracy rate in judging risk at these point. Similarly, Liu et al. [2011] alsoconcluded that the amount of traffic guide signs should not exceed 5 units to avoid increasing fixation. Jeng [2005] in his study found that traffic control devices within the vicinity of level crossings can confuse drivers. Lenne et al. [2011] determined that the locations of signs, roadway design, nature of actions required after level crossings, surrounding traffic, and pedestrians are important factors for the safety of level crossings. His study further recommended that rearranging the locations of signs may be the easiest improvement measure to be taken by roadway and railway safety administrators. The study observedalmost half of fatal level crossing crashes in Australia were caused by unintentional errors implying drivers failed to perceive the warnings signs or apprehend their meanings, even if the risk of the site is known and the warnings are clearly visible.

As much as literature abounds on RLC accidents globally, scholarly works onaccidents at these intersections in Nigeria geographic entity appear scarce. There is an obvious dearth of scholarly attention to these accidents in the past. It is therefore pertinent to shed more light on the pattern of accidents and mitigate unnecessary loss of life and property.

This concept identified three major component (i.e Education, Enforcement and Engineering) where deliberate accident management intervention can be undertaken in order to reduce risk. The education component is directed at improving the knowledge of all transport operators and users by providing enlightenment and education in the area of transportation safety. It is assumed that such interventions could improve accident risk through education and enlightenment. Similarly, the concept also identifies enforcement as playing an important role in improving the safety of transport operation through the regulating standards for the safe use of these infrastructure. This is often achieved through appropriate government agencies saddled with the specific responsibility of enforcing such rules and regulation to keep operators and users in check. Lastly, Engineering is concerned with enhancing technology and designs of transit infrastructure to improve safety. With specific reference to this study the engineering component is of particular interest since the study is focused on understanding what likely contribution the physical attributes of RLC infrastructure on accidents.

This the oretical framework explains causal association between accidents and specific environmental experiences. With origin in the field of medicine and epidemiology, concepts corresponding to Heinrich's first three dominoes would be Host (human), Agent (hazard), and Environment. From the perspective of epidemiological model an accident is defined as 'the unexpected, unavoidable unintentional act resulting from the interaction of host, agent, and environmental factors within situations which involve risk taking and perception of danger' Suchman, In [Heinrich et al., 1980]. Accident results in injuries and damages inflicted upon the people or the property. These effects are the measurable indices of the accidents. Conditions under which accident takes place are unexpected, unavoidable and unintentional act resulting from the predisposition characteristics and situational characteristics. 


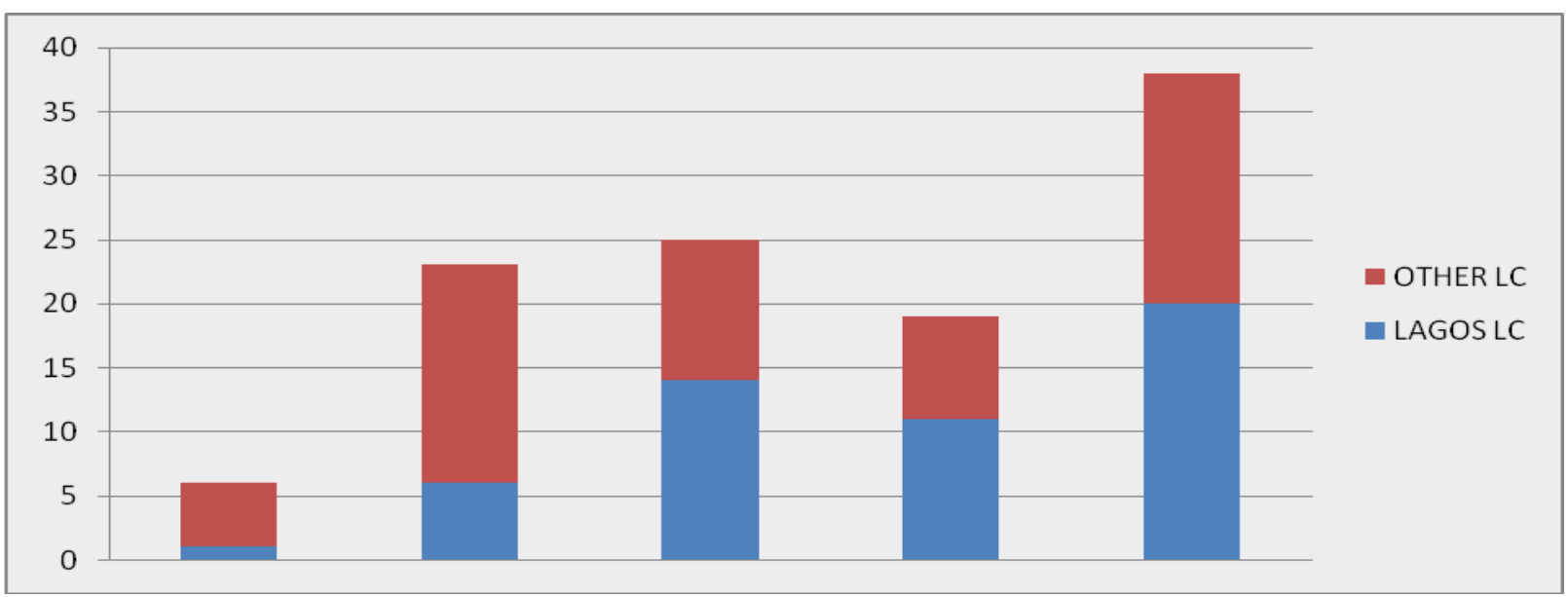

\section{Epidemiological Theory}

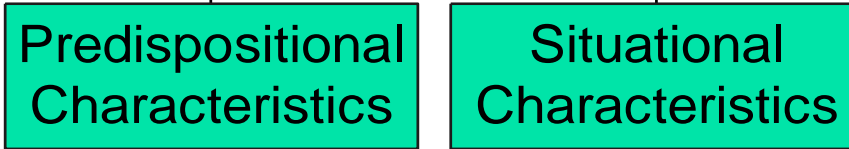

\section{Can cause or prevent accident conditions}

Figure 2. Showing the Epidemiological Theory Source : Caselli [2002]

Predisposition characteristics include the susceptibility of the people (host), hazardous environment, injury producing agent etc. Situational characteristics are risk assessment by individual, peer pressure, priorities of the supervisor and prevailing attitude. The model is mostly used to conceptualise etiologic factors for traffic injury and to identify potential preventive strategies for effective safety interventions [Sadauskas, 2003]. The theory is applicable to the understanding the contribution of the environmental factors to accidents causation, for this study the railway level crossing environment. Generally the nature of an environment may enhance or reduce the risk of accidents.

The following two hypothesis have been formulated for this study.
1: RLC Gateshave no significant effect on accidents occurrence within Lagos District

2: Thepresence of pedestrians has no significant effect on RLC accident.

\section{The Methods}

The data used in this study emanated from primary and secondary sources. Primary source include identification and measurement of the attributes and characteristics at each of the 12 level crossings identified within the Lagos metropolis. The study was interested in the spatial variation in the array of active and passive safety devices present or otherwise at each of the RLC. This include the presence or otherwise of barrier gates, traffic light control, signage. Other attributes of interest include low or heavy presence of 
pedestrians and automobile traffic all of which could influence the pattern of level crossing accidents. Secondary data emanated from records made available from the NRC headquarters in Ebute-Meta Lagos on RLC accidents in Lagos between year 2010-2014; published and unpublished text; internet websites and Journals for global records of level crossing accidents. The unique experimental design of the research made it necessary to visit each of the 12 RLC to observe and record physical safety features around them. The study further had interview with top management staffof NRC to augment the quality of information used for this study. Analysis involved the use of descriptive and inferential analytical methods. Descriptive analysis using graph and tables were necessary to present the pattern of RLC accident data within Lagos. The multiple regression analysis was usedin investigating the influence ofgates, pedestrian traffic, presence of traffic light, location of signage, vehicular traffic on the pattern of RLC accidents at each of the 12 level crossings identified in the metropolis. The independent variable accidents was regressed against independent dummy variables such as GATED; PEDESTRIAN TRAFFIC; PRESENCE OF TRAFFIC LIGHT; LOCATION OF SIGNAGE; VEHICULAR TRAFFIC.

The regression model used for the analysis is thus given by the equation;

$\mathrm{TACDT}=\mathrm{a}+\beta_{1} \mathrm{D}_{1}+\beta_{2} \mathrm{D}_{2}+\beta_{\mathrm{n}} \mathrm{D}_{\mathrm{n}}+\mathrm{e}$

where :

TACDT $=$ Total number of level crossing accidents $\mathrm{a}=$ regression constant

$\mathrm{b}=$ criterion of independent variable

$\mathrm{D}=$ independent dummy variables

(GATED;PEDESTRIAN TRAFFIC;PRESENCE OF TRAFFIC LIGHT; LOCATION OF

SIGNAGE;VEHICULAR TRAFFIC)

$\mathrm{e}=$ error term of the regression equation

\section{Result and Discussion}

The single track narrow gauge mainline in Lagos originates from the Iddo terminus South of Lagos state. Its track is part of the original design made by the British colonial administration in 1898. The track has anorth-western orientation was designed to link the hinterland of Nigeria with the ports [Badejo, 2004]. However the impact of urbanization over many decades has resulted in about 12 level crossing intersecting this trackbetween the Iddo terminus and the fringes of the Lagos metropolitan area. These crossingsinclude those in Oyingbo, Yaba, Jibowu, Mushin/Idioro, Ilupeju, ARENA, GRA, Ikeja, Guiness, Agege, Fagba and Alagbado. Casual observation reveals the safety devices attached to these location such as traffic signals and gates are dysfunctional at most locations. In other words, there are no working active warning electronic systems around these locations. Although many of the crossings are manned, staff activity is only obvious at crossings with heavy pedestrian movements such as Oyingbo, Yaba and Jibowu. Response to interview by NRC management also indicates there is buck-passing of the ownership/responsibility of these crossings between state government and NRC which continue to hamper the safety of these points.

The pattern of RLC accidents exhibited by the each of the crossings in Lagos within the period under consideration from figure 3 shows the Ilupeju crossing is the most important of accident 11 incidence. This is followed by the Ikeja GRA with 6 accidents, Guinness and Fagba at par both having 5 cases each. Next in line is the Agege crossing with 4 accidents to its credit while Oyingbo and Jibowu both recorded 3 accidents. The ARENA and Alagbado RLC recorded one accident each within the 5 year window while the Ikeja RLC by Anifowoshe area recorded no accident in the period. 


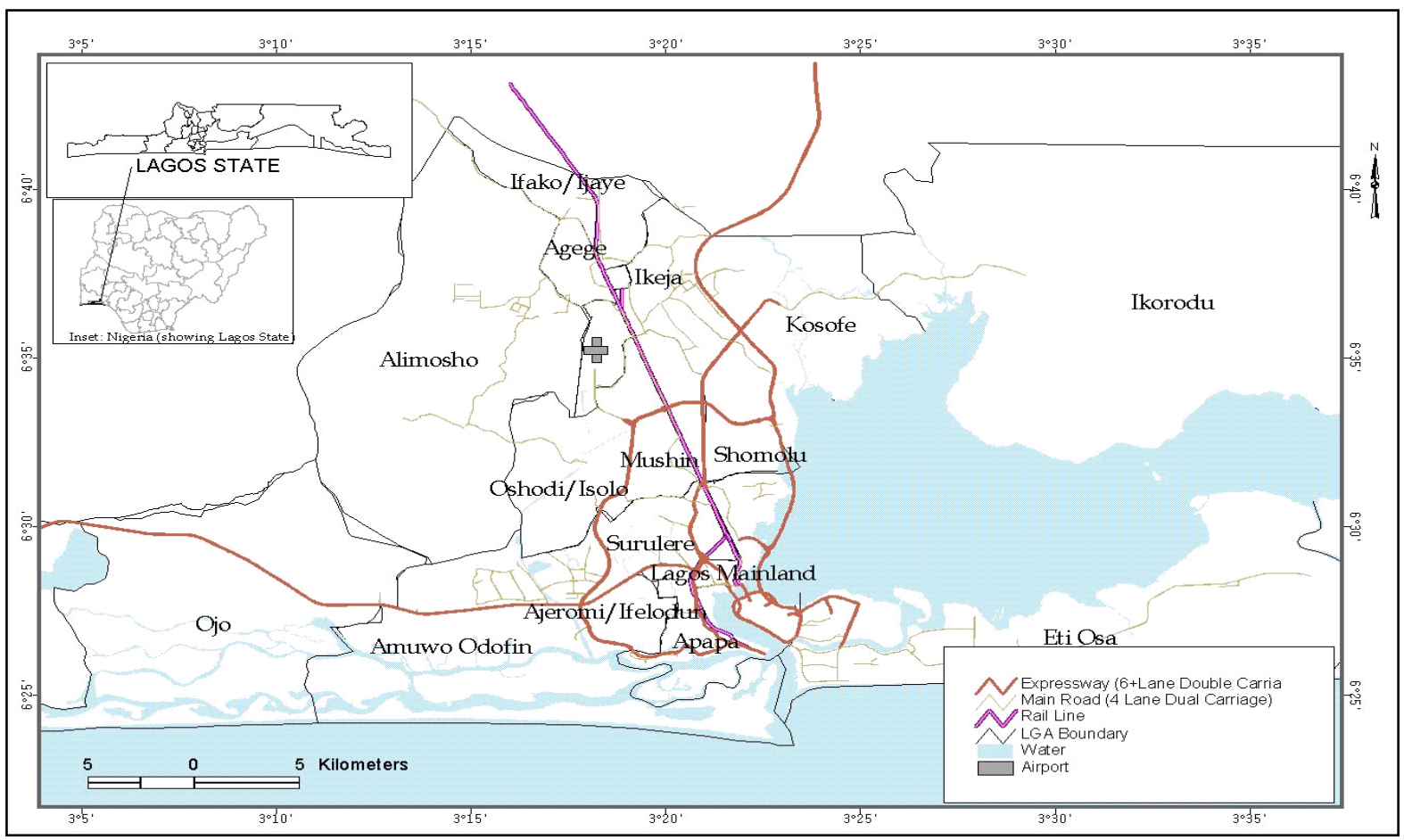

Figure 3. Map of Lagos State Showing Narrow Gauge Track in Lagos District Source : Adapted from Okanlawon [2007]

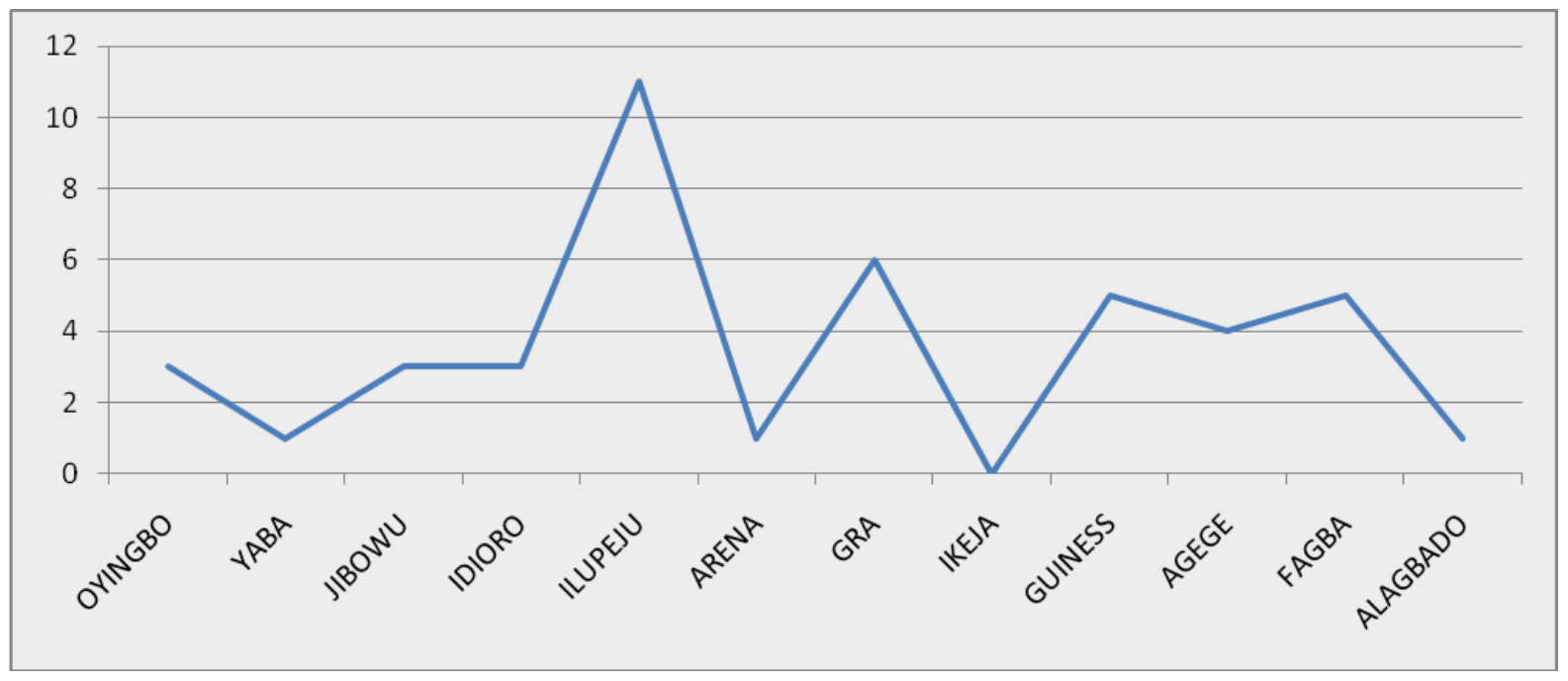

Figure 4. Showing a 5 year RLC accidents at different crossings in Lagos Source: Nigeria Railway Corporation 
Table 1. Model Summary for Regression

\begin{tabular}{lccccc}
\hline Variables & Acronym & UnStd. Reg. Coeff & Std. Reg. Coeff & Std. Error & T-Value \\
\hline LOCATION SIGN & LSGN & 4.761 & $0.782^{*}$ & 1.869 & 2.547 \\
VEHICLE DENSITY & VCHD & 3.439 & 0.519 & 1.869 & 1.839 \\
GATED & GTD & -4.955 & $-0.851^{*}$ & 1.957 & -2.532 \\
TRAFFIC LIGHT & T LIGHT & -6.058 & -0.538 & 3.154 & -1.921 \\
PEDESTRIANS & PEDACT & -4.690 & $-0.805^{*}$ & 1.680 & -2.792 \\
CONSTANT & & $5.548^{*}$ & & & 3.283 \\
MULTIPLE R & 0.827 & & & & \\
MULTIPLE R & 0.684 & & & & \\
MODEL ADJUSTED R ${ }^{2}$ & 0.421 & & & & \\
MODEL F-RATIO & 2.598 & & & & \\
$\mathrm{~N}$ & 12 & & & & \\
\hline
\end{tabular}

* Sig at 0.05 Dependent Variable: TACDTPredictors: (Constant), PEDACT, LSGN, Traffic Light, VCHD, GTD

\section{RLC Physical Attributes and Accident Occurence}

The independent variables entered for analysis for the regression model include nature of pedestrian activity (PEDACT), level of vehicular traffic (VCHD), presence of traffic light (TRAFFIC), location of the warning Signage (LSGN), presence of gate (GTD) are the variables entered against the dependent variable total accident(TACDT) within 5 years.From table 1 the regression analysis of the variables entered show the multiple $\mathrm{R}$ as 0.958 indicatinga very strong positive relationship between the independent variables and all dependent variables. The adjusted $\mathrm{R}^{2}$ of the model is 0.696 which indicates the all independent variable entered into the model was able to account for about $69.6 \%$ of the total variation in level crossing accidents within the Lagos metropolis. The remaining 30.4\% difference may be variables not accounted for within the model.From table 1, location of signage and vehicular density have positive unstandardized coefficients 4.761 and 3.439 respectively. Gates, traffic signals and pedestrians on the other have negative coefficient of-4.955, -6.058 and -4.690 respectively.Other result shows presence of pedestrians, signage, gates, traffic light and vehicular density as having the most important influence on RLC accidents with T values of 2.792, $2.547,-2.532,1.921$ and 1.839 respectively. Overall vehicular traffic makes the least contribution to accident variation at RLCs in Lagos.
The F-ratio in the ANOVA table tests shows that the independent variables as statistically insignificantly to predict the dependent variable, $F$ $=4.144, p>.0005$ i.e., the regression model is not a good fit of the data.Among the independent variables considered for this study, the location of signage, presence of gates and pedestrians arestatistically significant $(p<.05)$.

Recalling the hypothesis;

1: RLC Gates have no significant effect on accidents occurrence within Lagos District

p $(0.045)<0.05$ therefore reject $\mathrm{H} 0$ and accept $\mathrm{H} 1$ implying gates have significantimpact.

2: The presence of pedestrians has no significant effect on RLC accident.Again p (0.032) < 0.05, we reject $\mathrm{H}_{0}$ and accept $\mathrm{H}_{1}$ Presence of pedestrians significant reverse influence on accidents.

Based on the results of table one we can thus model level crossing accidents in Lagos metropolis based on their physical attribute as;

TACDT $=5.548+0.782($ LSGN $)+-0.851($ GTD $)+-$ 0.805(PADACT)

From the result so far it is obvious the physical attributes of level crossing play a crucial role in accident causation at level crossings in Lagos metropolis. The Location of signage asalso noted in the work of Lenne et al. [2011] plays a significant role in the pattern of accident occurrence and is also a significant factor in explaining the trend of accidents in the study area. This study further established that the closer the signage is to the RLC 
location the more accidents that will likely occur. This fact needs further investigation to see if it hold for other level crossings within the country, it will be of interest to see if this fact is again similar for road intersections in Nigeria. In view of the foregoing, the use of symbol should be encouraged as corroborated by Dickinson et. al. [2010], this is due to their ease of cognition and interpretation by level crossing users.

Furthermore on the result of study, the presence of pedestrians which showed areverse relationship with RLC accidents occurrence further confirms the position of Lenne et al. [2011] on the influence of pedestriansas an important factor for safety at these points. Although it is not immediately clear why it is so for metropolitan Lagos, however there is good suspicion thatit is closely associated with street trading activities common around level crossings. There traders more or less may be acting as the "alarm bell" forother RLC users when a train is approaching. The "commotion" they set off probably may help in raising an early alert toall users of level crossing of an impending danger of an oncoming train. The presence of gates which isanother significant variable appear to be playing its expected effect as the presence of gates also shows a reverse influence on accidents. Finally presence of traffic signal or otherwise which is the last of the variables considered in this work appear not to have any obvious effect on level crossing accidents based on the result of this study. The reason may not be farfetched. Most, if not all of thetraffic signal equipments for road vehicle users are either dysfunctional or without any source of reliable electricity. Although present at most crossings, they do not actively contribute to safety by warning users of any impeding risk or danger of an approaching train.

\section{Conclusion}

Based on the findings of this study the following recommendations are provided as a way to improve the safety of Level crossings within Lagos and Nigeria at Large.

i. Installation of traffic camera at RLC intersection within the metropolis to properly capture the behaviour of motorist and possibly penalize erring bhaviour. ii. The data capturing and record at NRC be improved to capture elements of incidence reporting such as time of incidence, type of vehicle, direction and speed of train etc.

iii. Conscious effort should be made by relevant authority to improve the visibility of signs at RLC and place them farther away from these intersections.

iv. All level crossing should be gated and manned.

v. Very visible road marking should be put in place at every level crossing to make them more obvious.

vi. Active warning system such as traffic light signal and alarm bellsat these intersections should be made functional. Reliable alternativepower source like solar energy should be explored.

vii. Lagos State government and the management of NRC should work more closely together in their effort to reduce the rising number of RLC accidents within the state.

In conclusion, this study has identified several physical attributes of RLC within Lagos metropolis that have significant influence on accidentsrequiring policy intervention in effort to improve safety. Policy that must be introduced must focus on improving the safety associated with the physical attributes of these level crossing. Specifically such policy among other must target making RLC signage more visibility to users, active gate operations and installation of alarm bells to simulate the effect of pedestrian activity. Effort to arrest the rising cases of accidents in Lagos and Nigeria at large may also require studies to that will examine other dimension particularly administration of right of way which are ubiquitous in foreign research and are scarce in Nigerian context. Studies are indeed desirable to also examine the nature ofsafe counter measures to all manner of unsafe human behaviour as rightly noted by Kumarand and Panday (2013). Understandingthe contribution of the human user element to the pattern of accidents across the country is critical to the developing a safe use model to manage the ngative effects of these intersections in Nigeria. 


\section{References}

Afxentis, D. (1994). Urban railway level crossings: Civil engineering working paper. Melbourne: Monash University.

Asenime, C. and Mobereola, D. (2015). Traffic behaviour at a signalised intersection in Metropolitan Lagos. American Journal of Social Issues and Humanities. 5 (2), 453-561

Atomode, T. I. (2013). Assessment of traffic delay problems and characteristics at urban road Intersections: A Case Study of Ilorin, Nigeria. IOSR Journal of Humanities And Social Science. 12, (4), 06-16

Badejo, B.A..(1999). Resuscitating Nigeria rail system: Strategies and options. Journal of Transport Development Initiatives. 1 (1), 2539.

Badejo, B.A., (2004) The Nigerian railways and socio-economic development of Yoruba land: A historical perspective. In Toyin Falola (ed). Perspectives on Yoruba History Culture. University of Texas, Austin Texas USA.

Borowsky, A., Shinar, D. and Parmet, Y. (2008). Sign location, sign recognition, and driver expectancies.Transportation Research Part F, $11,459-465$.

Caird, J.K., Creaser J.I., Edwards C.J. and Dewar. (2002). A human factors analysis of highwayrailway grade crossing accidents in Canada. Transport Canada, Montreal, Canada.

Cairney, P. (2003). Prospects for improving the conspicuity of trains at passive railway crossings. Road safety research report CR 217. ACT: Australian Transport Safety Bureau.

Crundall, D. and Underwood, G. (2011). Hand Book of Traffic Psychology, 137-148. Elsevier.

Dubbudu, R. (2015). Accidents in Indian Railways: Review of the last 5 years. Making data meaningful .https://factly.in/indian-railwayaccidents-statistics-review-last-5-years/

Edquist J., Stephan, K., and Wigglesworth, L. M. (2009). A literature review of human factors safety issues at Australian level crossings. Melbourne: Monash University Accident Research Centre.

Enokela, J.A. and. Ibanga, E. J. (2008). Microcontroller-based highway-railway level crossing traffic controller. Continental. Journal of Engineering Sciences. 3 (2) 56- 63
European Transport Safety Council (ETSC). http://etsc.eu/international-level-crossing awareness-day-2015

Federal Railroad Administration. Accident/Incident Report for year 2015. http://safetydata.fra.dot.gov/OfficeofSafety/ publicsite/summary.aspx

Gil, M., Multer, J., and Yeh, M. (2007). Effects of active warning reliability on motorist compliance at highway-railroad grade crossings (DOT/FRA/ORD-09-06). Washington D.C.: U.S. Department of Transportation.

Jeng, O. (2005). Survey of driver perceptions of railroad and light rail warning devices/grade crossings. Report No.: FHWA-NJ-2004-025 (Tech. Rep.). Federal Transit Administration, U.S. Department of Transportation pp74.

Kiunsi, R. B. (2013). A review of traffic congestion in Dar es Salaam city from physical planning perspective. Journal of Sustainable Development. 6 (2), 94-103.

Kumarand, A. and Panday, M. N. (2013). A study of safety awareness of railway crossing. International Journal of Engineering Research \& Technology 2 (12), ISSN: 2278-0181

Lenne, M. G., Salmon, P. M. and Young, K. L. (2011). An exploratory study assessing driver behaviour at highway-rail grade crossing using on-road test vehicles, $3^{\text {rd }}$ International Conference on Road Safety and Simulation.

Leibowitz, H.W. (1985). Grade crossing accidents and human factors engineering. American Scientist. 73 (6), 558- 562.

Liu, B., Sun, L. and Rong, J., (2011). Driver's visual cognition behaviors of traffic signs based on eye movement parameters. Journal of Transportation Systems Engineering and Information Technology.

Odeleye, J. A. (2000). Public-private participation to rescue railway development in Nigeria. Japan Railway and Transport Review Journal. 23 (42-49), 104-111.

Odeleye, J. A. (2015).The Challenges to Competitive Rail Transport System in Nigeria. A paper delivered at National Railway Conference, Sheraton Hotel and Towers Abuja $10 / 31 / 2015$ 
Stephens, M. S. and Ukpere, W. I. (2011). Accidents and level of intelligence: A view from the Nigerian experience. Journal of Human Ecology. 35 (2), 75-84

UIC Global Safety Report Leaflet No.470 on Railway Accidents 2014 in Europe. http://uic.org/com/uic-enews/470/article/international-union-ofrailways?page $=$ iframe_enews

Wallace, A. (2008). Motorists behaviour at railway level crossings: the present context in
Australia. Unpublished $\mathrm{PhD}$ thesis, Queensland University of Technology.

Wigglesworth, E. (2008). Ergonomics, safety and railway level crossings. Ergonomics Australia. 21 (4), 4-13. 